\title{
MENINGKATKAN PEMAHAMAN INTEGRITAS DIRI MELALUI LAYANAN INFORMASI DENGAN MEDIA AUDIO VISUAL PADA SISWA KELAS VIII SMP NEGERI 1 SUNGAI PINYUH
}

\author{
Riki Maulana $^{1)}$, Novi Wahyu Hidayati ${ }^{2)}$, Desy Allmahny ${ }^{3)}$ \\ ${ }^{1)}$ IKIP PGRI Pontianak, Pontianak, Indonesia \\ E-mail: rikimaulana556@gmail.com \\ 2) IKIP PGRI Pontianak, Pontianak, Indonesia \\ E-mail:noviagus@gmail.com \\ ${ }^{3)}$ IKIP PGRI Pontianak, Pontianak, Indonesia \\ E-mail:desy201788@gmail.com
}

\begin{abstract}
Abstrak. Penelitian ini bertujuan untuk meningkatkan pemahaman integritas diri siswa kelas VIII Sekolah Menengah Pertama Negeri 1 Sungai Pinyuh, metode penelitian yang digunakan dalam penelitian ini yaitu Penelitian tindakan, dengan bentuk penelitiannya adalah Penelitian Tindakan Bimbingan Dan Konseling (PTBK). Untuk mengumpulkan data penelitian, digunakan teknik pengumpul data yaitu (1) Teknik observasi langsung, (2) Teknik komunikasi tidak langsung, (3) Teknik komunikasi langsung, (4) Teknik Studi Dokumenter, sedangkan alat pengumpul datanya yaitu (1) Pedoman observasi, (2) Panduan wawancara, dan (3) Skala psikologis, (4) Dokumentasi. Penelitian dilakukan dikelas VIII D Sekolah Menengah Pertama Negeri 1 Sungai Pinyuh dengan jumlah subyek penelitian 32 orang siswa. Teknik Analisis Data berarti proses mencari dan menyusun secara sistematis data yang diperoleh dari wawancara, observasi, Skala Psikologi dan dokumentasi Hasil pelaksanaan layanan informasi dengan media audio visualuntuk meningkatkan pemahaman integritas diri siswa kelas VIII Sekolah Menengah Pertama Negeri 1 Sungai Pinyuh mendapat presentase rata-rata $77 \%$ dengan kategori baik.
\end{abstract}

Kata Kunci: Integritas Diri; Layanan Informasi; Media Audio Visual Karir

\section{Pendahuluan}

Dalam menjalani kehidupan sehari-hari sifat integritas diri sangat diperlukan. Khususnya bagi peserta didik yang kelak menjadi generasi penerus bangsa sekaligus agen perubahan dalam masyarakat. Untuk mengoptimalkan peran tersebut, peserta didik harus bisa mengimplementasikan integritas dalam kegiatan sehari-hari. Karena integritas diri adalah salah satu kunci kesuksesan hidup peserta didik, tanpa adanya integritas peserta didik tidak akan sukses dalam berinteraksi dengan orang lain dan tanpa adanya integritas diri peserta didik tidak akan bisa mencapai keinginannya. Seperti yang diungkapkan Richard Buckminster Fuller (dalam [1]) Integritas adalah inti dari setiap kesuksesan.
Integritas diri adalah sebuah keunggulan diri pribadi yang menjadikan seseorang hidup lebih sehat dan tanpa beban, karena mereka menjalankan hidupnya jauh dari aneka kepura-puraan dan kepalsuan. Di mana pun dia berada, dan kondisi apa pun yang menekannya, ia tetap hidup konsisten dengan nilai-nilai yang dianutnya. Orang yang memiliki integritas diri mampu memberi pengaruh besar dan positif dalam kehidupan, bahkan untuk generasi penerus mereka, melalui keteladanan dan apa saja yang mereka selalu perjuangkan. Integritas diri merupakan cermin kepribadian seseorang.

Integritas diri memungkinkan semua perasaan diungkapkan dengan kejujuran dan ketulusan meskipun individu harus melaksanakan sesuatu yang tidak menyenangkan. Jika diterima, Indvidu-individu yang 
mempunyai integritas diri akan memancarkan kepercayaan diri dan sikap yang tidak mementingkan diri sendiri. Seperti yang diungkapkan Spencer Johnson (dalam [1]) Integritas adalah mengabarkan kebenaran pada diri sendiri. Kejujuran adalah mengabarkan kebenaran pada orang lain.

Integritas diri merupakan nilai yang mendasari perilaku yang didasarkan pada upaya menjadikan dirinya sebagai orang yang selalu dapat dipercaya dalam perkataan, tindakan, dan pekarjaan memiliki komitmen dan kesetiaan pada nilai-nilai kemanusiaan dan moral. Menurut [2], disebutkan beberapa karakteristik yang secara konsisten diperlihatkan oleh orang yang berintegritas diri tinggi, yakni: Menyadari bahwa hal-hal kecil itu penting; Bertanggung jawab; Menciptakan kepercayaan; Menepati janji; Jujur dan rendah hati; serta Komitmen.

Integritas diri sangat dibutuhkan dalam pembinaan perkembangan siswa untuk belajar memahami dan menyesuaikan diri dengan lingkungan sekolah, dengan integritas diri yang tinggi akan menjadikan siswa yang selalu tampil dengan fisik yang segar, Memiliki kehidupan rohani yang mendalam, dan dapat diandalkan secara intelektual, Tidak mudah terbawa emosi, sabar dan kuat dalam mengahadapi tantangan dan tekanan, serta luwes dalam pergaulan.

Peran Guru Bimbingan dan Konseling dalam upaya memberikan pemahaman mengenai integritas diri bagi siswa sangat penting. Bimbingan dan Konseling di sekolah sangat berperan dalam upaya memberikan pemahaman pada siswa tentang integritas diri. Salah satu bantuan yang diberikan kepada siswa yaitu melalui layanan informasi, menurut [3] layanan informasi adalah kegiatan memberikan pemahaman kepada individu-individu yang berkepentingan tentang berbagai hal yang diperlukan untuk menjalani suatu tugas atau kegiatan, atau untuk menentukan arah suatu tujuan atau rencana yang dikehendaki.Tujuan layanan ini agar individu memiliki pengetahuan (informasi) yang memadai, baik tentang dirinya maupun tentang lingkungannya, lingkungan penguruan tinggi, masyarakat, serta sumber-sumber belajar termaksud internet. informasi yang diperoleh individu sangat diperlukan agar individu lebih mudah dalam membuat perencanaan dan pengambilan keputusan [4].

Bagi seorang pendidik di bidang Bimbingan dan Konseling, harus dapat memanfaatkan media dalam penyampaian informasi. Media merupakan alat bantu bagi guru dalam penyampaian pesan yang akan disampaikan kepada peserta didik secara langsung. Seperti yang diungkapkan oleh [5] media pembelajaran dapat dipahami sebagai "segala sesuatu yang dapat menyampaikan dan menyalurkan pesan dari sumber secara terencana sehingga tercipta lingkungan belajar kondusif dimana penemrimanya dapat melakukan proses belajar secara efisien dan efektif". Dalam hal ini media audio visual perlu digunakan dalam proses pemberian layanan informasi tentang integritas diri. Menurut [6] Media Audio visual merupakan media yang tepat menampilkan unsur gambar dan suara secara bersamaan peda saat mengomunikasikan pesan atau informasi. Dengan adanya media audio visual dapat membantu bagi pendidik untuk menyampaikan informasi kepada peserta didik secara langsung.

SMP Negeri 1 Sungai Pinyuh adalah salah satu sekolah di Sungai Pinyuh yang menerapkan pendidikan karakter yaitu religius, nasionalis, mandiri, gotong royong dan integritas. Salah satu yang harus ditingkatkan pada diri siswa adalah integritas diri. Usia siswa yang masih remaja cenderung tidak menyadari bahwa hal-hal kecil itu penting, kurang bertanggung jawab, tidak memiliki kepercayaan, tidak menepati janji, tidak jujur dan rendah hati, serta tidak memiliki komitmen. Integritas diri yang rendah paling banyak ditemukan pada siswa kelas delapan (VIII).

Berdasarkan obsevasi dan wawancara yang dilaksanakan peneliti di SMP Negeri 1 Sungai Pinyuh khususnya kelas VIII masih dijumpai sebagian siswa yang tidak memiliki integritas diri dengan ditemukannya gejala-gejala pada siswa seperti tidak menyadari bahwa hal-hal kecil itu penting misalnya berbohong untuk hal sederhana, mengambil sesuatu milik orang lain tanpa izin, sering tidak bertanggung jawab atas perbuatannya, tidak memiliki pendirian, tidak jujur dalam mengerjakan tugas dan dalam ujian, tidak konsisten dengan apa yang dikatakan dan dipikirkan, serta menunjukkan pemahaman integritas diri yang rendah.

Meningkatkan pemahaman integritas diri dapat dilakukan melalui layanan informasi dengan menggunakan media audio visual. Dalam pelaksanaan sebelum ini Guru Bimbingan dan Konseling memberikan layanan informasi masih menggunakan metode ceramah di depan kelas. Siswa biasanya menganggap materi tersebut sangat membosankan dan kurang menarik, sehingga materi yang disampaikan oleh Guru Bimbingan dan Konseling tidak diterima siswa dengan baik. Padahal banyak informasi yang sangat penting dan bermanfaat bagi siswa yang diberikan oleh Guru Bimbingan dan Konseling. Guru Bimbingan dan Konseling dapat menggunakan media pembelajaran salah satunya berupa media audio visual dengan berupa film, power point, VCD, dan sound slide dalam memberikan layanan informasi.

Rumusan penelitian ini yaitu Bagaimanakah Meningkatkan Pemahaman Integritas Diri Melalui Layanan Informasi Dengan Media Audio Visual Pada Siswa Kelas VIII SMP Negeri 1 Sungai Pinyuh, sedangkan tujuan penelitian ini yaitu Meningkatkan Pemahaman Integritas Diri Melalui Layanan Informasi Dengan Media Audio Visual Pada Siswa Kelas VIII SMP Negeri 1 Sungai Pinyuh.

\section{Metode}

Metode penelitian adalah cara yang digunakan oleh peneliti dalam mengumpulkan data untuk mendapatkan data dengan tujuan yang tertentu. Metode yang dianggap tepat dalam penelitian ini adalah menggunakan metode penelitian tindakan (action research). Sedangkan Bentuk penelitan dalam peneltian ini adalah penelitan tindakan Bimbingan dan Konseling (PTBK). Penelitan tindakan Bimbingan dan Konseling (PTBK) dilakukan dalam proses layanan bimbingan dan konseling sehingga fokus penelitiannya berada pada proses layanan bimbingan dan konseling yang melibatkan konselor dan konseli. 
Subjek penelitian adalah keseluruhan kumpulan individu atau sumber data yang berkaitan dengan masalah penelitian. Dalam penelitian ini adalah siswa kelas VIII SMP Negeri 1 Sungai Pinyuh Kelas subjek penelitian yang menjadi perhatian utama subjek dalam penelitian ini adalah kelas VIII D dengan jumlah 32 siswa, 18 siswi dan 14 siswa. Pelaksanaan penelitian ini dilaksanakan di SMP Negeri 1 Sungai Pinyuh pada siswa kelas VIII D. Penelitian ini dilaksanakan pada tanggal 29 April 2018 sampai dengan 3 Juni 2018 yang dilakukan tindakan dalam dua siklus penelitian dan dilaksanakan sesuai dengan rencana penelitian.

Dalam penelitian ini teknik pengumpulan data yang dianggap cocok oleh peneliti adalahteknik observasi langsung, teknik kemunikasi langsung, teknik komunikasi tidak langsung, teknik studi dokumenter. Dari teknik pengumpulan data yang digunakan, maka dapat diketahui bahwa alat pengumpul data yang digunakan adalah pedoman observasi, panduan wawancara, skala psikologi, dokumentasi. Teknik analisis data yang digunakan yaitu analisis deskriptif kuantitatif dengan cara menggunakan rumus persentase, yaitu dengan cara skor yang diperoleh dibagi dengan skor total dikalikan $100 \%$. Analisis ini digunakan untuk mengolah skala psikologi. Teknik analisis kualitatif digunakan untuk menganalisis hasil observasi berupa catatan lapangan dan wawancara.

\section{HASIL DAN PEMBAHASAN}

\section{A. HASIL}

\section{Gambaran Pemahaman Siswa tentang Integritas Diri Sebelum Tindakan}

Setelah skala psikologi disebarkan dan semua data telah dikumpulkan, maka dapat dijabarkan hasil data pemahaman siswa tentang integritas diri di kelas VIII SMP Negeri 1 Sungai Pinyuh. Hasil perhitungan dijabarkan dalam bentuk tabel dengan perhitungan persentase secara rinci dinyatakan tabel I.

TABEL I

HASIL ANALISIS DATA SKALA PSIKOLOGI INTEGRITAS DIRI SEBELUM TINDAKAN

\begin{tabular}{clcccc}
\hline No & Aspek Variabel & $\begin{array}{c}\text { Skor } \\
\text { Aktual }\end{array}$ & $\begin{array}{c}\text { Skor } \\
\text { Ideal }\end{array}$ & \% & $\begin{array}{c}\text { Katego } \\
\text { ri }\end{array}$ \\
\hline 1 & $\begin{array}{l}\text { Menyadari bahwa } \\
\text { hal-hal kecil itu } \\
\text { penting, }\end{array}$ & 487 & 896 & $54 \%$ & Cukup \\
2 & $\begin{array}{l}\text { Bertanggung jawab } \\
3\end{array}$ & 410 & 768 & $53 \%$ & Cukup \\
$\begin{array}{l}\text { Menciptakan } \\
\text { kepercayaan } \\
\text { Menepati janji }\end{array}$ & 322 & 640 & $50 \%$ & Kurang \\
5 & $\begin{array}{l}\text { Jujur dan rendah hati. } \\
6\end{array}$ & 524 & 896 & $58 \%$ & Cukup \\
\hline Komitmen, & 355 & 768 & $46 \%$ & Kurang \\
\hline Rata-rata keseluruhan aspek & 2692 & 5120 & $53 \%$ & Cukup \\
\hline
\end{tabular}

Berdasarkan penjelasan di atas, dapat digambarkan sebagaimana yang tertera dalam grafik 1sebagai berikut:

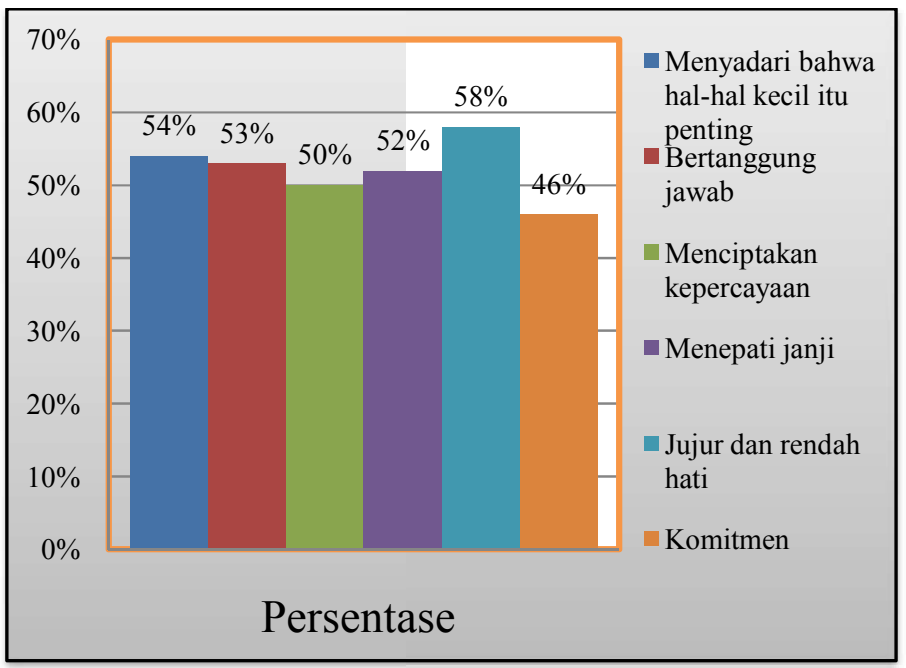

Grafik 1 Persentase Aspek Integritas Diri Siswa Sebelum Tindakan

\section{Deskripsi Pelaksanaan Layanan Informasi Dengan Media Audio Visual}

Setelah diketahui kondisi awal mengenai pemahaman integritas diri yang diperoleh dari penyebaran skala psikologis, maka selanjutnya peneliti akan memberikan layanan informasi dengan media audio visual yang dilakukan sebanyak 2 kali pertemuan setiap siklusnya. Materi yang dibahas dalam layanan informasi ini disediakan langsung oleh peneliti.

1. Pelaksanaan Siklus I

\section{a. Perencanaan (Planning)}

Pelaksanaan siklus I dilaksanakan pada hari senin, tanggal 30 april 2018. Sebelum dilaksanakannya kegiatan peneliti menyusun terlebih dahulu rencana pelaksanaan layanan (RPL) dari kegiatan yang akan dilaksanakan. Agar kegiatan peneliti lebih aktif dan tidak lupa menyiapkan pedoman observasi yang akan diamati oleh guru bimbingan dan konseling selama kegiatan berlangsung.

\section{b. Tindakan (Action)}

Pertemuan pertama, pelaksanaan tindakan dilakukan pada Hari Senin Tanggal 30 April 2018, Materi Integritas, Kegiatan layanan informasi ini pada pertemuan pertama siswa terlibat dan siswa yang menjadi subjek dalam penelitian ini harus hadir semua. Sebelum kegiatan dimulai ketua kelas menyiapkan diri dan berdo'a sesuai dengan kepercayaan dan keyakinan masing-masing. Pada tahap awal ini peneliti mengucapkan salam dan perkenalan diri terlebih dahulu, tujuannya agar menjalin hubungan yang baik dengan siswa dan siswa mau terbuka dalam menyampaikan pendapat masing-masing selama proses kegiatan berlangsung, dan permainan agar siswa tidak terlalu tegang. Dalam kegiatan peneliti menjelaskan materi yang akan dibahas mengenai integritas diri. Banyak hal yang peneliti bahas dan singgung terkait dengan integitas diri dan peneliti mengaitkan dengan video yang menjadi 
media penyampaian sekaligus peneliti menjelaskan poinpoin dari materi yang disampaikan tersebut. Sehingga penjelsan peneliti selesai, peneliti memberikan kesempatan kepada siswa untuk bertanya dan berpendapat terkait dengan materi yang disampaikan dan melakukan refleksi dari hasil kegiatan dengan pemahaman mengenai integritas.

Pertemuan kedua, pelaksanaan tindakan dilakukan pada Hari Rabu Tanggal 9 Mei 2018 Materi Integritas Diri. Pelaksanaan tindakan layanan informasi dengan media audio visual di siklus pertama pertemuan kedua ini semangat siswa semakin bertambah dan siswa menjadi subjek penelitian hadir semua. Seperti biasanya Sebelum kegiatan dimulai ketua kelas menyiapkan diri dan berdo'a sesuai dengan kepercayaan dan keyakinan masing-masing sehingga apa yang dipelajari dapat bermanfaat. Pada tahap awal ini peneliti mengucapkan salam dan menanyakan kabar dan hal-hal yang paling disukai pada siswa serta siswa diberikan ice breaking, tujuannya agar siswa bersemangat selama proses pemberian layanan informasi tersebut. Peneliti menyamapaikan topik pembahasan lanjutan dari pertemuan pertama, manfaat integritas diri, sebelum masuk dalam melanjutkan materi peneliti sedikit menanyakan materi yang sudah dibahas sebelumnya. Masuk dalam kegiatan inti, peneliti langsung menjelaskan materi pembahasanya yaitu manfaat integritas diri, setelah selesainya materi yang disampaikan peneliti meminta keterlibatan siswa untuk saling berinteraksi mengenai pembahasan yang disampaikan, setelah itu siswa diberikan film tentang integritas diri, meminta siswa untuk menganalisi film yang diberikan, siswa di bagi menjadi 6 kelompok dan setiap kelompok berdiskusi serta akan mempresentasikan hasil diskusinya. Menanyakan kembali kepada siswa tentang materi yang sudah disampaikan, mengevaluasi hasil dari penjelasan materi yang sudah disampaikan.

\section{c. Pengamatan (observation)}

Hasil dari observasi kegiatan layanan informasi dengan media audio visual dalam siklus I pertemuan pertama dan pertemuan kedua masih ada beberapa tahap pelaksanaan layanan informasi yang tidak dilakukan.

\section{d. Refleksi (reflection)}

Berdasarkan dari penjelasan di atas, peneliti menyimpulkan bahwa pada sadarnya pemahaman integritas diri sudah terlihat. Keberhasilan dan kegagalan pada siklus pertama yaitu sebagian siswa masih belum memperhatikan penjelasan yang diberikan dengan baik, sehingga siswa masih ada yang belum memahami materi yang disampaikan. Hal ini disebabkan dikarenakan siswa belum sepenuhnya menunjukan keaktifannya dalam mengikuti kegiatan informasi yang diberikan dan siswa masih malu dan takut untuk mengemukakan pendapatnya dan mengajukan pertanyaan kepada peneliti berkaitan dengan materi yang dibahas dalam pemberian layanan tersebut. Dilihat dari pedoman observasi pelaksanaan layanan informasi siklus I pertemuan pertama dan pertemuan kedua masih ada beberapa tahap pelaksanaan layanan informasi yang tidak dilakukan. Oleh karena itu, peneliti mengadakan siklus II untuk memperbaiki kelemahan dan kekurangan pada siklus I.

2. Pelaksanaan Siklus II

a. Perencanaan (planning)

Pelaksanaan siklus II dilaksanakan pada hari jum'at tanggal 11 Mei 2018, sebelum dilaksanakannya kegiatan peneliti menyusun rencana pelaksanaan layanan (RPL) dari kegiatan yang akan dilaksanakan. Selanjutnya peneliti meyiapkan pedoman observasi yang digunakan guru bimbingan dan konseling dalam mengamati langkah tindakan yang akan dilaksanakan.

b. Tindakan (action)

Pertemuan pertama, pelaksanaan tindakan dilakukan pada Hari Senin Tanggal 14 Mei 2018 Materi karakteristik Integritas Diri. Sebelum kegiatan mulai seperti biasa ketua kelas menyiapkan dan memimpin do'a menurut kepercayaan dan keyakinan masing-masing sehingga apa yang akan dipelajari dapat bermanfaat dan proses belajar megajar lancar. Pada tahap awal seperti biasa peneliti mengucapkan salam pembuka dan menanyakan kabar siswa.Setelah itu, peneliti menjelaskan tentang materi karakteristik integritas diri dan peneliti menjelaskan bahwa untuk memiliki integritas diri yang tinggi harus mengetahui karakterisitik integritas diri, baik terhadap fisik maupun sosial sambil menunjukan terkait materi tersebut sampai penjelasan selesai peneliti memberikan pertanyaan kepada siswa terkait materi yang dibahas. Siswa pun sudah mulai mau bertanya dan mengeluarkan pendapatnya sehingga melakukan refleksi dari hasil kegiatan layanan informasi dengan media audio visual berkaitan dengan pemahaman siswa mengenai integritas diri.Kegiatan akhir, peneliti menyimpulkan hasil kegiatan, menanyakan kembali kepada siswa tentang materi yang sudah disampaikan, mengevaluasi hasil dari penjelasan materi yang sudah disampaikan.

Pertemuan kedua pelaksanaan tindakan dilakukan pada Hari Rabu Tanggal 30 Mei 2018Materi : Pribadi yang memiliki integritas diri. Seperti biasa sebelum kegiatan dimulai ketua kelas menyiapkan dan memimpin do'a agar apa yang akan disampaikan dapat bermanfaat. Pada tahap awal peneliti mengucapkan salam pembuka dan menanyakan kabar siswa dan mengabsen kehadiran siswa dipertemuan kedua ini siswa nampak semangat dan suasana kelas pun terasa nyaman dari sebelumnya sehingga membuat peneliti mudah dalam menyampaikan materi layanan informasi tentang integritas diri dengan media audio visual. Sebelum masuk kemateri peneliti sedikit memainkan permainan agar siswanya lebih bersemangat lagi dan memudahkan peneliti dalam menyampaikan materi layanan informasi tersebut.

Pada pertemuan kedua ini, peneliti menyampaikan topik pembahasan lanjutan dari pertemuan pertama dari siklus II, Pribadi yang Memiliki Integritas Diri. Sepeti biasanya sebelum masuk kemateri peneliti membahas materi sebelumnya dan peneliti menanyakan kembali kepada siswa terkait materi yang sudah dijelaskan sudah nampak siswa yang mulai mau berpendapat meskipin masih ada yang takut. Peneliti langsung menjelaskan 
materi tentang Pribadi yang Memiliki Integritas Diri, setelah selesainya materi dijelaskan peneliti meminta keterlibatnya siswa untuk saling berinteraksi mengenai materi yang dibahas

c. Pengamatan (observation)

Hasil dari observasi kegiatan layanan informasi dengan media audio visual selama siklus II dapat disimpulkan bahwa dapat meningkatkan pemahaman integritas diri siswa, dan pelaksanaan layanan informasi dengan media audio visual sudah baik sesuai dengan tahapan-tahapannya.

\section{d. Refleksi (Reflection)}

Berdasarkan penjelasan diatas, pada siklus II peneliti menyimpulkan bahwa pada dasarnya pemahaman perserta didik mengenai integritas diri sudah baik. adapun keberhasilan dari siklus II yaitu siswa selalu memperhatikan penjelasan dari peneliti terkait materi yang dibahas sehingga siswa memahami apa yang di sampaikan diluhat dari keaktifan siswa dalam mengikuti kegiatan layanan informasi yang diberikan siswapun tidak lagi takut dan malu untuk bertanya dan takut berpendapat maupun mengajukan pertanyaan. Dilihat dari penjelasan tersebut, peneliti menyimpulkan bahwa pada siklus II ini sudah berhasil dalam pelaksanaan.

\section{Gambaran Pemahaman Siswa tentang Integritas Diri Sesudah Tindakan}

Pemberian skala psikologi kedua yaitu dilakukan sesudah melakukan tindakan di dalam kelas, hal ini dilakukan untuk mengetahui tingkat pemahaman siswa terhadap integritas diri setelah diberikan layanan informasi dengan media audio visual. Dengan diberikan skala yang kedua, maka diperoleh hasil yang tertera pada tabel II dibawah ini:

TABEL II

HASIL ANALISIS DATA SKALA PSIKOLOGI INTEGRITAS DIRI SETELAH DIBERIKAN TINDAKAN

\begin{tabular}{|c|c|c|c|c|c|}
\hline No & Aspek Variabel & $\begin{array}{c}\text { Skor } \\
\text { Aktual }\end{array}$ & $\begin{array}{l}\text { Skor } \\
\text { Ideal }\end{array}$ & $\%$ & $\underset{\text { ri }}{\text { Katego }}$ \\
\hline 1 & $\begin{array}{l}\text { Menyadari bahwa hal- } \\
\text { hal kecil itu penting, }\end{array}$ & 701 & 896 & $78 \%$ & Baik \\
\hline 2 & Bertanggung jawab & 593 & 768 & $77 \%$ & Baik \\
\hline 3 & $\begin{array}{l}\text { Menciptakan } \\
\text { kepercayaan }\end{array}$ & 470 & 640 & $73 \%$ & Cukup \\
\hline 4 & Menepati janji adalah & 872 & 1152 & $76 \%$ & Baik \\
\hline 5 & Jujur dan rendah hati. & 730 & 896 & $81 \%$ & Baik \\
\hline 6 & Komitmen & 551 & 768 & $72 \%$ & Cukup \\
\hline \multicolumn{2}{|r|}{-rata keseluruhan aspek } & 3917 & 5120 & $77 \%$ & Baik \\
\hline
\end{tabular}

Berdasarkan penjelasan di atas, dapat digambarkan sebagaimana yang tertera dalam grafik 2 sebagai berikut:

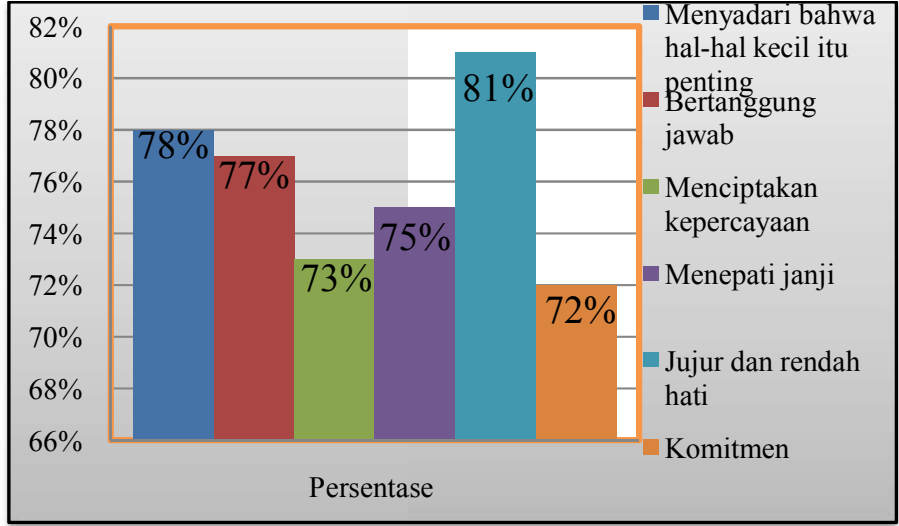

Grafik 2 Persentase Aspek Integritas Diri Siswa Sesudah Tindakan

Perbandingan Pemahaman Siswa tentang Integritas Diri Sebelum Dan Sesudah Tindakan

Berdasarkan pengamatan terdapat hasil pada siklus I dan siklus II. Dari data skala psikologi sebelum dan sesudah dilaksanakannya tindakan penelitian melalui layanan informasi dengan media audio visual, pemahaman integritas diri dapat dilihat di dalam grafik 3 sebagai berikut:

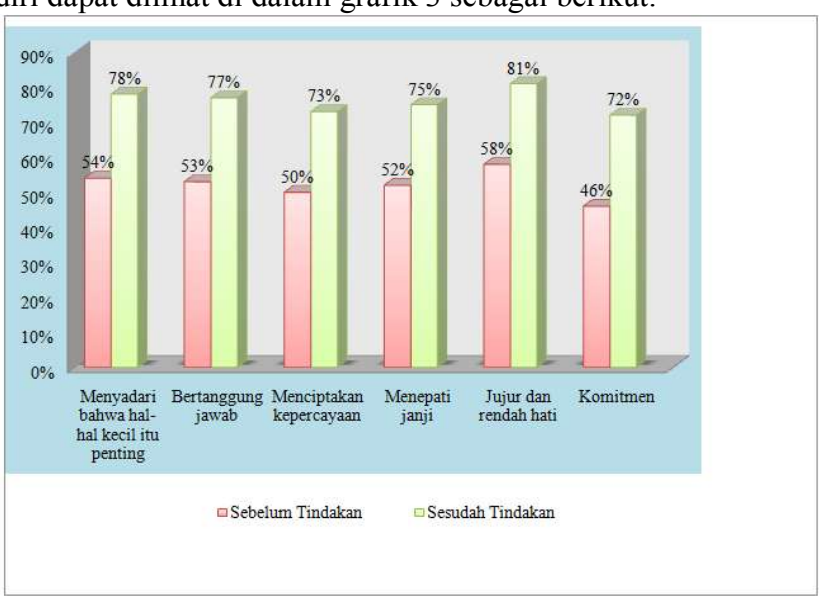

Grafik 3 Perbandingan Sebelum dan Sesudah Diberikan Layanan Informasi Dengan Media Audio Visual

Berdasarkan dari hasil pelaksanaan siklus I dan II, diperoleh kesimpulan bahwa melalui pelaksanaan layanan informasi dengan media audio visual dapat meningkatkan integritas diri. Hal ini dapat dilihat dari analisis skala psikologis sebelum diberikan tindakan dengan presentase 53\% dengan kategori cukup, dan dapat diinterpretasikan bahwa siswa kelas VIII SMP Negeri 1 Sungai Pinyuh masih belum memahami pengertian integritas diri, manfaat integritas diri, karakteristik integritas diri, serta pentingnya integritas diri dikehidupan. Dan setelah dilaksanakan tindakan pemahaman siswa meningkat sesuai dengan harapan peneliti dengan persentase $77 \%$ dengan kategori baik dan dapat diinterpretasikan bahwa siswa kelas VIII SMP Negeri 1 Sungai Pinyuh, sudah memahami pengertian integritas diri, manfaat integritas diri, karakteristik integritas diri, serta 
pentingnya integritas diri dikehidupan. sama serta dapat memahami integritas diri dan pentingnya integritas diri dikehidupan.

\section{B. PEMBAHASAN}

Berdasarkan dari hasil pelaksanaan siklus dapat kesimpulan bahwa melalui pelaksanaan layanan informasi dengan media audio visual dapat meningkatkan integritas diri. Hal ini dapat dilihat dari analisis skala psikologis sebelum diberikan tindakan dengan presentase 53\% dengan kategori cukup, dan dapat diinterpretasikan bahwa siswa kelas VIII SMP Negeri 1 Sungai Pinyuh masih belum memahami pengertian integritas diri, manfaat integritas diri, karakteristik integritas diri, serta pentingnya integritas diri dikehidupan. Dan setelah dilaksanakan tindakan pemahaman siswa meningkat sesuai dengan harapan peneliti dengan persentase $77 \%$ dengan kategori baik dan dapat di interpretasikan bahwa siswa kelas VIII SMP Negeri 1 Sungai Pinyuh, sudah tidak malu-malu saat berbicara dan bertanya, sudah tertarik dan mampu merespon pada apa yang disampaikan penulis, selalu bersemangat, fokus pada saat peneliti menjelaskan materi dan berani menjawab saat ditanya, sudah adanya rasa ingin tahu dan mudah diajak bekerja sama serta dapat memahami integritas diri dan pentingnya integritas diri dikehidupan.

Dalam penerapan layanan informasi dengan media audio visual sudah dilaksanakan dengan maksimal, meskipun pada awal pertemuan terdapat kendala, yaitu terdapat beberapa siswa masih malu berbicara, masih kurang aktif dalam diskusi, belum tertarik dan belum fokus pada apa yang peneliti sampaikan. Terlihat pada hasil observasi yang dilakukan oleh guru bimbingan dan konseling pada siklus I pertemuan pertama dan kedua bahwa pada tahap persiapan peneliti belum bisa menjalin keakraban kepada siswa, serta beberapa siswa belum begitu terlibat dengan aktif pada saat proses pelaksanaan kegiatan. Akan tetapi sebisa mungkin peneliti berusaha agar kendala tersebut bisa diatasi terbukti dengan siklus II peneliti sudah bisa mengatasi dengan adanya perubahan pada diri siswa

Penelitian ini dapat juga diperkuat dengan penelitian relevan [7] dengan judul "Efektivitas Layanan Informasi dengan Menggunakan Media Audio Visual dalam Meningkatkan Sikap Siswa terhadap Kedisiplinan Sekolah". Dalam penulisan ini menguji layanan informasi dengan menggunakan media audio visual sangat efektif untuk meningkatkan sikap siswa terhadap kedisiplinan sekolah; Dilihat dari permasalahan dalam penelitian ini diperkuat dengan penelitian relevan yaitu [8] dengan judul "Pemberian Layanan Bimbingan Kelompok untuk Meningkatkan Integritas Diri Kelas XI SMA Yayasan Hidayatul Islam Medan". Hasil penelitian menunjukan bahwa Dari hasil penelitian dapat disimpulkan bahwa layanan bimbingan kelompok mempunyai pengaruh terhadap peningkatan integritas diri.

Dari penelitian relevan dan penelitian yang penulis lakukan sama-sama membahas tentang layanan informasi dan media audio visualtetapi dengan tujuan yang berbeda. Penelitian ini bertujuan untuk meningkatkan pemahaman integritas diri siswa melalui layanan informasi dengan media audio visual kelas VIII SMP Negeri 1 sungai pinyuh.

Layanan informasi dengan media audio visual mempunyai manfaat besar bagi individu dalam meningkatkan pemahaman integritas diri, seperti dapat memberikan pengalaman belajar yang bisa dicontoh individu, membekali individu dengan berbagai macam pengetahuan tentang lingkungan yang diperlukan untuk memecahkan masalah yang dihadapi berkenaan dengan pendidikan, pekerjaan memungkinkan individu dapat menentukan arah hidup untuk menjadi orang yaang sukses di masa depan, dengan cara memberikan informasi seputar integritas diri. Berdasarkan hasil observasi layanan informasi dengan media audio visual pada siklus I dan II terdapat peningkatan pemahaman integritas diri berdasarkan aspek-aspeknya.

\section{KESIMPULAN}

Berdasarkan hasil penelitian yang telah dilaksanakan oleh peneliti maka dapat diambil kesimpulan sebagai berikut:

1. Gambaran pemahaman siswa tentang integritas diri di kelas VIII SMP Negeri 1 Sungai Pinyuh. Berdasarkan hasil penyebaran skala psikologi sebelum tindakan dengan kategori cukup, dengan hasil yang telah dicapai berdasarkan perhitungan rata-rata keseluruhan aspek.

2. Pelaksanaan layanan informasi dengan media audio visual untuk meningkatkan pemahaman siswa mengenai integritas diri berjalan lancar sesuai dengan perencanaan yang sudah dibuat sebelumnya. Yang dilakukan dengan 3 tahap yaitu : kegiatan awal, kegiatan inti dan kegiatan akhir. Pada pelaksanaan layanan informasi ini dinyatakan baik.

3. Pemahaman siswa mengenai integritas diri melalui layanan infomasi dengan media audio visual di kelas VIII SMP Negeri 1 Sungai Pinyuh dikatakan baik, hal ini dilihat dari peningkatan sebelum tindakan dan sesudah tindakan setelah diberikan layanan informasi dengan media audio visual. Tindakan siklus 1 menjadi kategori cukup baik dan meningkat sesuai dengan harapan peneliti setalah dilaksanakan tindakan siklus II dengan kategori baik.

\section{DAFTAR PUSTAKA}

[1] Rintyastini, Y., \& Charlotte, S. Y. (2015). Bimbingan dan Konseling untuk Kelas $I X$. Jakarta: Erlangga.

[2] Gostick, A., \& Telford, D. (2006). Keunggulan Integritas. (Alih bahasa: Fahmi Ihsan). Jakarta: PT Bhuana Ilmu Populer.

[3] Prayitno \& Amti, E. (2015). Dasar-Dasar Bimbingan dan Konseling. Jakarta: PT. Rineka Cipta.

[4] Nurihsan, A. J. (2006). Bimbingan Dan Konseling Dalam Berbagai Latar Kehidupan. Bandung: PT Refika Aditama.

[5] Rosyada, D., \& Syaf, A. H. (2008). Media Pembelajaran. Jakarta: Gaung Persada Press.

[6] Wati, E. R. (2016). Ragam Media Pembelajaran. Yogyakarta: Kata Pena.

[7] Natalia, N., Firman., \& Dahardis. (2015). Efektifitas Layanan Informasi Dengan Menggunakan Media Audio Visual Dalam Meningkatkan Sikap Siswa Terhadap Kedisiplinan Sekolah. Jurnal Konseling \& Pendidikan, 3(2), 40-48.

[8] Saragih, M. (2012). Pengaruh Pemberian Layanan Bimbingan dan Kelompok Untuk Meningkatkan Intergritas Diri Kelas XI SMA Yayasan Hidayatul Islam Medan Tahun Ajaran 2012/2013. Skripsi, Fakultas Ilmu Pendidikan Universitas Negeri Medan: Diterbitkan. 